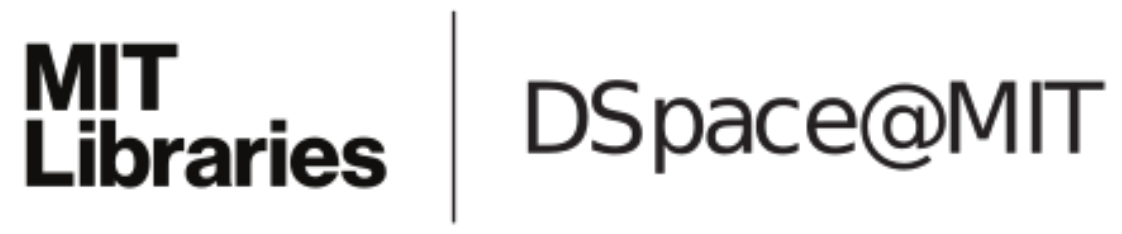

\author{
MIT Open Access Articles
}

The Miracle and Tragedy of the 2020 U.S. Election

The MIT Faculty has made this article openly available. Please share how this access benefits you. Your story matters.

Citation: Persily, Nathaniel and Stewart, Charles. 2021. "The Miracle and Tragedy of the 2020 U.S. Election." Journal of Democracy, 32 (2).

As Published: $10.1353 / J 0 D .2021 .0026$

Publisher: Project Muse

Persistent URL: https://hdl.handle.net/1721.1/138152

Version: Original manuscript: author's manuscript prior to formal peer review

Terms of use: Creative Commons Attribution-Noncommercial-Share Alike 


\title{
The Miracle and Tragedy of the 2020 Election
}

\author{
Nathaniel Persily, Stanford University \\ Charles Stewart III, The Massachusetts Institute of Technology
}

Draft of February 22, 2021

\begin{abstract}
The 2020 election was both a miracle and a tragedy. In the midst of a pandemic, election administrators pulled off a safe, secure, and professional election. Still, lies of voter fraud have cemented in the minds of tens of millions of Americans that the election was rigged.

As the first wave of the pandemic overtook the nation right as the presidential election season was beginning, most states responded by delaying their primaries and maximizing opportunities to vote by mail. We review how the quick actions of many states led to a salvaging of the primary season, but also led to two cautionary tales, from Wisconsin and New York, that illustrated the disasters that could befall both mail and in-person voters if the nation did not act quickly. We recount the combination of actions taken by governors, state legislators, health officials, judges, and civil society to adapt election administration to the exigent realities of the pandemic and to cope with the logistical challenges state and local election officials faced.

We discuss metrics of success in the adaptations that took place - record-high turnout, widespread voter satisfaction, a doubling of mail voting without a concomitant increase in problems often associated with absentee ballots, and the recruitment of hundreds of thousands of new poll workers. We also explore how the competing narrative of dysfunction and a "stolen election," propagated by President Trump and his supporters, led not only to the insurrection at the Capitol on January 1, but also to a historically deep chasm at the mass level between partisans in their trust of the election process and outcome. We conclude by noting that many states will be considering legislation that re-litigates the election by addressing non-problems, rather than building on the triumphs of the election.
\end{abstract}




\title{
The Miracle and Tragedy of the 2020 Election
}

\author{
Nathaniel Persily, Stanford University \\ Charles Stewart III, The Massachusetts Institute of Technology
}

The 2020 election was both a miracle and a tragedy. It was a miracle in that election administrators, facing unprecedented challenges from a pandemic, were able to pull off a safe, secure, and professional election in which a record number of Americans turned out to vote. It was also a tragedy, though, because, despite these heroic efforts, lies about voter fraud and the performance of the system have cemented a perception among tens of millions of Americans that the election was "rigged." This manufactured distrust has deeply damaged our democracy; the path to repairing it is not at all clear.

The Capitol Insurrection on January 6 will forever constitute the enduring image of the 2020 election and the distrust that accompanied it. Despite the heroism and success we detail in this article, over one hundred of members of Congress voted to question and overturn the results in one or more states. Indeed, even once the specter of violence and mob rule became apparent, they voted just hours after the Capitol was overrun to decertify Pennsylvania's electoral slate.

The enduring images of the 2020 election should have been much different. In the primary elections, the picture looked bleak, as poll worker and polling place shortages caused long lines of frustrated voters to risk their lives, and thousands of absentee ballots were rejected in places with little experience with mail voting on a grand scale. In the general election, however, a young army of new poll workers, wearing personal protective equipment (PPE), and often administering the voting from behind lucite barriers, staffed polling places. Absentee 
voting also set records, as rates of canceled mail ballots were dramatically lower than before the pandemic.

How did the country pull off a successful election under pandemic circumstances? What changes to the election infrastructure were necessary to accomplish this task? How can we reconcile this measurable success with strongly held convictions from a sizable share of the electorate that the election was rigged? These are the questions this article seeks to answer.

\section{How Bad Things Could Have Been}

Given the howling, unfounded partisan criticism that the election was "rigged" and "disastrous," it is difficult in hindsight to reimagine what a true election disaster would have looked like and how close we came. But the meltdown in several states during the primary elections painted an ominous picture of institutional collapse for the general election. In several respects, the election system benefited from the timing of the pandemic, coming as it did in the middle of the presidential primary season but hitting hardest just as Joe Biden wrapped up the nomination. The baptism by fire in the primaries provided the necessary lessons to address the pandemicrelated problems in mail and polling place voting in order to avoid a repeat in November.

The primary season began with few COVID-related concerns, as Iowa, New Hampshire, South Carolina, and Nevada held their primaries and caucuses in late February. Super Tuesday (March 3) also came at the beginning of the pandemic, with California the only state of the fourteen that had recorded a case by then. Ohio, with its primary scheduled for March 17, became the first state to sound the alarm when the state's public health director ordered all polling places closed. The state then switched to almost all-mail balloting and extended the time 
to vote through April 28. ${ }^{1}$ Most other states with March primaries then postponed their elections until May and June. By late March, governors throughout the country issued stay-at-home orders. The presidential nomination process escaped pandemic-related disaster by just a few weeks, as Biden's nomination seemed by that point all but assured.

Wisconsin was one of the states that did not reschedule its April 7 primary, and it became the cautionary tale as to what to avoid when conducting elections during a pandemic. ${ }^{2}$ On the ballot for the primary was also an election for the State Supreme Court, so the flexible attitude other states would take in postponing the primary was replaced with partisan concerns about what delay might mean for the candidates' fortunes. As the primary date approached and over 2500 COVID cases were confirmed in the state, Governor Tony Evers issued an Executive Order to postpone the election, but Republican legislative leaders successfully sued and the Wisconsin Supreme Court ordered the election to go ahead as scheduled. Only on April 6 did it become clear that the primary would be held the next day and, pursuant to a U.S. Supreme Court decision five days earlier, the deadline for absentee ballots would not be extended.

The last-minute wrangling between the governor, legislature, and the courts exacerbated the state's lack of preparedness to run a primary during the pandemic. The state faced a shortage of 7000 poll workers, causing the Governor to mobilize 2400 members of the National Guard. The state closed only 15 percent of its planned polling places, but the largest cities reduced polling locations dramatically. Milwaukee went from 180 to 5 polling places, Green Bay

\footnotetext{
${ }^{1}$ For a listing of primary date changes see "2020 State Primary Election Dates," National Conference of State Legislatures, 3 November 2020, https://www.ncsl.org/research/elections-and-campaigns/2020-state-primary-election-dates.aspx.

${ }^{2}$ For a complete description of the Wisconsin primary, which is only summarized here, see Grace Scullion et al., "Wisconsin's 2020 Primary in the Wake of COVID-19," Stanford-MIT Healthy Elections Project, 30 June 2020, https://healthyelections.org/sites/default/files/202006/Wisconsin\%E2\%80\%99s\%202020\%20Primary\%20in\%20the\%20Wake\%20of\%20COVID-19.pdf.
} 
from 31 to 2, Kenosha County from 22 to 10 . Hardest hit were voters of color, whose turnout was more than twenty points lower than whites in the primary.

Absentee voting, however, rescued the Wisconsin primary from complete disaster. ${ }^{3}$

Nearly 60 percent of the 1.5 million voters who turned out cast their ballots absentee, compared to 3.6 percent in the 2016 primary. Total turnout declined from 2.1 million in 2016, when competitive primaries for both parties brought out both Democrats and Republicans. (Most of the dropoff in 2020 was concentrated among Republicans.) Rejection rates of absentee ballots decreased from 2016, as 13,614 ballots were rejected because of "insufficient certification" and another 7,085 were rejected because they were late or did not have a postmark. Rejection rates for African Americans were about twice that of whites, however, and rejections for first time voters were about a third higher than for previous voters.

The warning shot of the Wisconsin primary was heard loud and clear by the states that followed it. Most shifted significantly to mail balloting for the remainder of the primary season. As a result, absentee voting exploded in the primaries, but only in states that voted after March. Among states that voted in February and March, mail-ballot usage was virtually unchanged. ${ }^{4}$

Beginning with Wisconsin's April 7 primary and ending with Louisiana (July 11), every state saw a dramatic increase in mail ballot usage - on average, 60 percentage points greater than 2016. Figure 1 depicts the shift in the mode of voting in the primaries that took place once the pandemic hit.

\footnotetext{
${ }^{3}$ See John Curiel and Angelo Dagonel, "Wisconsin Election Analysis," Stanford-MIT Healthy Elections Project, 6 August 2020, https://healthyelections.org/sites/default/files/202008/Wisconsin\%20Election\%20Analysis\%20Version\%202\%281\%29.pdf.

4 The exceptions were California, which was already transitioning to a quasi vote-by-mail system in most counties, Michigan, which had passed a referendum providing for no-excuse absentee voting in the 2018 election, and Florida, which has a flexible vote-by-mail system that swung into play during its March 17 primary.
} 
[Figure 1 about here]

With increasing rates of mail balloting came increases in the number of rejected ballots. A national study conducted by NPR estimated over 550,000 primary mail ballots were rejected, as compared to 318,728 in the 2016 general election. ${ }^{5}$ Given the dramatic rise in mail balloting, though, the share of rejected ballots even for the primary went down in many states. Georgia's decline in mail ballot rejections was particularly notable, dropping from 17 percent in the 2016 primary to less than 1 percent in $2020 .{ }^{6}$ Not every state experienced a drop, however. North Carolina - a state with relatively few mail ballots - saw its mail-ballot rejection rate climb from 7 percent in the 2016 primary to 10 percent in 2020, mostly because of a dramatic increase in ballots lacking a signature. ${ }^{7}$ New York, as well, caught the national spotlight because of its high rejection rate.

Just as Wisconsin provided the cautionary tale for polling place voting, New York City's June 23 Primary painted the worst case scenario for mail balloting. New York City rejected 84,000 absentee ballots -- a rejection rate of 21 percent. $^{8}$ Among other reasons, ballots were rejected because they arrived late, they were missing postmarks, and the voter failed to sign the oath envelope. Ballot design problems and poor coordination with the Post Office seemed to underlie many of the rejections.

\footnotetext{
${ }^{5}$ Pam Fessler and Elena Moore, "More Than 550,000 Primary Absentee Ballots Rejected In 2020, Far Outpacing 2016," Hawai'i Public Radio, 21 August 2020, https://www. hawaiipublicradio.org/post/more550000-primary-absentee-ballots-rejected-2020-far-outpacing-2016\#stream/0.

${ }^{6}$ Kevin DeLuca, "Georgia Primary Election Analysis," Stanford-MIT Healthy Elections Project, 15 September 2020, https://healthyelections.org/sites/default/files/202010/georgia election analysis memo.pdf.

${ }^{7}$ Blair Read, "North Carolina Election Analysis," Stanford-MIT Healthy Elections Project, 19 July 2020, https://healthyelections.org/sites/default/files/2020-08/North\%20Carolina\%20Memo\%281\%29.pdf.

${ }^{8}$ Carl Campanile, Nolan Hicks, and Bernadette Hogan, "Over 80,000 mail-in ballots disqualified in NYC primary mess," New York Post, 5 August 2020, https://nypost.com/2020/08/05/84000-mail-in-ballotsdisqualified-in-nyc-primaryelection/?utm source=twitter sitebuttons\&utm medium=site\%20buttons\&utm campaign=site\%20buttons \&fbclid=IwAR1zrizOijbQjTXuL6LXC9pD5DItj9vTpi60kEqP78Kdshrli8AGjEJgYrE.
} 
Thus, the primary period provided a wake-up call not only to election administrators and policymakers, but to the public about how bad things might be in November if an unprecedented effort was not expended to plan for the November election. New York highlighted problems with absentee voting, and illustrated what might happen if states with more traditional laws and practices did not change their ways, at least on an emergency, one-time basis. Wisconsin was an object lesson about the fragility of the in-person voting infrastructure, and a reminder that millions of people still preferred to vote in person even when doing so was dangerous. The nation's election community had its work cut out for it in preparing for the fall.

\section{Mobilization to Address COVID's Challenge to the Election Infrastructure}

The shift to mail voting and healthy polling places in the general election did not just "happen." States had to change their laws. Governors, health officials, and judges needed to impose emergency measures to deal with the pandemic.

Twenty-nine states and the District of Columbia enacted 79 different bills to expand voting access in 2020. Some states, such as California, New Jersey, Vermont, and Nevada, mailed every voter a ballot for the first time. Twelve states mailed absentee ballot applications to all voters, eight expanded eligibility to vote by mail (for example by eliminating excuserequirements or designating COVID-concerns as an excuse), four enacted new "notice and cure" processes so voters could remedy mistakes with mail balloting, four provided prepaid postage for all mail ballots, four extended ballot receipt deadlines, and five moved to permit preprocessing of mail ballots.

\footnotetext{
9 “Voting Laws Roundup 2020," Brennan Center for Justice, 8 December 2020, https://www.brennancenter.org/our-work/research-reports/voting-laws-roundup-2020-0; "Voting Procedure Modifications for the General Election," Ballotpedia, 19 November 2020, https://ballotpedia.org/Changes to election dates, procedures, and administration in response to the coronavirus (COVID-19) pandemic, 2020\#Summary of developments.
} 
With respect to polling places, states relaxed rules on who could become a poll worker, increased poll worker compensation, and set quotas for the minimum number of polling places. Some of these changes were permanent, while others were designated emergency measures to deal with the pandemic. Many states that did not willingly make these changes were forced to do so by courts as a result of litigation. ${ }^{10}$

In addition to action by policy makers and courts, an unprecedented civil-society-led effort emerged to assist local election administrators in dealing with the pandemic. The Stanford-MIT Healthy Elections Project, which we led, was a small part of that effort. Other organizations, such as the Center for Technology and Civic Life (CTCL), the Center for Secure and Modern Elections, the National Vote at Home Institute, Democracy Works, the Center for Civic Design, the Center for Election Innovation and Research, and a multitude of state-based organizations worked together with election officials to provide the resources and technical assistance to make the transition to mail voting and safe polling places.

Poll worker recruitment represents one visible impact of this civil society mobilization. Following the primaries, poll worker shortages appeared to present a critical threat to the November election. Roughly half of poll workers in previous elections were over the age of 61, a group at greater risk from the virus. States as varied as Wisconsin, Georgia, and Alaska experienced drastic shortfalls in poll workers for the primaries.

A host of organizations representing students (Campus Compact and Students Learn Student Vote), lawyers (Association of ProBono Counsel), doctors, and other groups mobilized to fill the need. None were more influential than PowerthePolls.org. Working with the database of election offices provided by WorkElections.com and a multitude of partners at the state level,

10 "Mail Voting Litigation during the Coronavirus Pandemic," Stanford-MIT Healthy Elections Project, 29 October 2020, https://healthyelections.org/sites/default/files/2020-11/Mail Voting Litigation.pdf. 
Power the Polls initiated a national poll worker recruitment program that signed up over 700,000 volunteers. (To give some context, roughly a million people served as poll workers in the 2016 election.) Exactly how many of those who signed up ended up serving remains to be better understood, but poll worker shortages did not appear to afflict any major jurisdiction in the November election.

Perhaps the most unprecedented outside effort to bolster the election infrastructure came in the form of philanthropic contributions to election offices. Through the CARES Act, Congress had appropriated $\$ 400$ million for assistance to election jurisdictions. ${ }^{11}$ In the end, private philanthropy contributed even more. Mark Zuckerberg and Priscilla Chan, alone, contributed $\$ 400$ million. ${ }^{12}$ This money was administered through a CTCL grant program to over 2500 election jurisdictions. It paid for staffing, equipment for mail balloting, ballot drop boxes, PPE for poll workers, election security, polling place rentals and sanitation, staffing and real estate costs, poll worker training, and a host of other functions. By all accounts, these added funds were critical to the success administration of the election. The same could be said for corporate in-kind donations, such as the NBA arenas repurposed as early voting centers or other kinds of donations made through groups, such as Business for America. ${ }^{13}$

One final set of outside actors deserves mention: the internet platforms. Widely reviled given their role in disinformation and foreign meddling in the 2016 campaign, Google and Facebook developed products for 2020 to provide and amplify authoritative information from

\footnotetext{
${ }^{11}$ H.R. 748, CARES Act, Public Law 116-136.

12 Nicholas Riccardi, "Mark Zuckerberg donates \$100M more to help election offices," Associated Press, 13 October 2020, https://apnews.com/article/virus-outbreak-election-2020-technology-local-electionselections-c2dcfde7fc750b7dd64243b0cf7fbb69.

13 "NBA, NBA arenas \& facilities being used for 2020 election," NBA.com, n.d., https://www.nba.com/nbaarenas-polling-place-voting-center-2020-election; Alex Tausanovitch, Sarah Bonk, and Richard Eidlin, "17 Ways Companies Can Help Americans Vote Safely," Center for American Progress, 9 September 2020, https://www.americanprogress.org/issues/democracy/reports/2020/09/09/490167/17-ways-companiescan-help-americans-vote-safely/.
} 
election officials. The Google Civic Information API, developed from the Voting Information Center run by Democracy Works in consultation with local election offices, powered numerous web portals that provided information on polling places, voter registration procedures, ballot drop box locations, and much else. ${ }^{14}$ Facebook's Voting Information Center provided similar data, as well as information from third parties, like the Bipartisan Policy Center, which would be deployed in users' feeds to mute the impact of other, potentially less authoritative, stories, on the voting process. ${ }^{15}$ In addition, the portal, which also produced top-of-feed reminders, assisted over 4.5 million people in registering to vote and over 100,000 people to sign up as poll workers. ${ }^{16}$

\section{Success Against All Odds}

The most basic measure of the success of an election is turnout. By this metric, the 2020 election was an unalloyed success by American standards. Measured by raw numbers, 160 million votes were cast in 2020, up by more than 20 million from 2016. This amounted to two-thirds of the eligible electorate, six points higher than 2016, and the highest turnout rate since $1904 .{ }^{17}$

Turnout as a percentage of the voting-eligible population increased in every state, although there was considerable variation. (See Figure 2.) The most significant turnout increases were in the West and much of the eastern seaboard. The smallest increases - in the range of the low single digits - occurred in the country's midsection, where states took the least effort to increase access to the polls, and the presidential race was mostly uncompetitive.

\footnotetext{
14 "Google Civic Information API," Google, n.d., https://developers.google.com/civic-information. 15 "Voting Information Center," Facebook, n.d., https://www.facebook.com/votinginformationcenter. 16 "A Look at Facebook and U.S. 2020 Elections," Facebook, December 2020, https://about.fb.com/wpcontent/uploads/2020/12/US-2020-Elections-Report.pdf.

17 "Voter Turnout Data," United States Elections Project, n.d., http://www.electproject.org/home/voterturnout/voter-turnout-data.
} 
[Figure 2 about here]

It is natural to wonder the degree to which heightened electoral competition in the battleground states, access (or lack thereof) to mail ballots, and the availability of Election Day registration (EDR) may have contributed to greater turnout surges in the places they occurred. The most competitive states, measured by the margin of victory, and states that instituted EDR after 2016 saw the biggest turnout increases that pass the standard criteria of statistical significance. ${ }^{18}$ Mailing a ballot to all voters and adopting no-excuse absentee voting did not have statistically significant effects.

\section{The successful expansion of mail balloting}

Turnout was not the whole story, of course. The main election administration story was the shift to mail balloting. Even if efforts to encourage more voting by mail played a modest role in boosting turnout, the shift to vote-by-mail was as much an effort to protect public health in a high-intensity election as anything. As seen in Figure 3, the 2020 Election accelerated a twodecade long evolution away from Election Day voting, by suddenly cutting Election Day voting in half while doubling the usage rate of voting by mail.

[Figure 3 about here]

The national trend toward voting by mail masks considerable variability in the degree of change across states and, in some cases, the mix between Election Day, early in-person, and mail voting. This is illustrated in Figure 4, which uses a ternary plot to show the changing mix of voting modes from 2016 to 2020 . This plot employs points to show the mix of voting modes used in each state, as reported by voters in the 2020 Survey of the Performance of American

\footnotetext{
18 The findings discussed in this paragraph are based on multivariate regression analysis available from the authors upon request.
} 
Elections. Attached to each point is a line that indicates the distribution of modes in 2016.

Election-Day voting dominated in the states toward the top of the plot; states toward the lower right mostly voted in person before Election Day; and mail balloting dominated in states toward the lower left.

[Figure 4 about here]

The most common path of travel in the graph is toward the southwest: that is, toward greater use of mail ballots, but not entirely. Of the 14 states in which over $80 \%$ of voters cast ballots on Election Day in 2016, for instance, six (Mississippi, Oklahoma, Missouri, New York, Rhode Island, Virginia, and Kentucky) saw voters employ a mix of early in-person and mail ballots in 2020, while the other eight (Alabama, Delaware, New Hampshire, Connecticut, Oklahoma, Minnesota, and New Jersey) saw an almost exclusive shift to voting by mail.

Post-election responses to the Survey of the Performance of American Elections (SPAE) describe the reasons behind the shift to mail balloting. ${ }^{19}$ Overall, 58.5 percent of respondents who stated they were very worried about family members catching COVID also reported they voted by mail, compared to 27.5 percent who said they were not worried at all. This difference in mail-ballot uptake is not entirely explained by partisan differences of opinion over the pandemic. Even among Republicans, 41.5 percent who were very worried about COVID voted by mail, compared to 25.2 percent for those not worried at all. (The corresponding Democratic figures were 62.1 percent and 35.2 percent, respectively.)

A state's legal regime dramatically affected its rate of absentee balloting. Looking at the cross-section in 2020, voters in states with no-excuse absentee ballot laws used mail ballots at a

\footnotetext{
19 The SPAE is a post-election survey undertaken by MIT every year since 2008 , intended to gauge the experience of voters in the most recent presidential election, and designed to allow comparisons across states. In 2020,the sample size was 10,800, with no fewer than 200 interviews in any state.
} 
higher rate (55.1 percent) than voters in other states (34.9 percent); voters in states that mailed ballots to all registered voters likewise voted by mail at a greater rate ( 80.5 percent) than elsewhere (39.9\%). The only common policy that did not appear to affect usage rates was mailing an absentee ballot application to all voters. ${ }^{20}$ Based on statistical analysis we have performed, the biggest increases in mail-ballot usage from 2016 to 2020 occurred in states that mailed ballots to all registered voters (19-point increase) and that were largely Democratic. ${ }^{21}$

During the pre-election period, election officials and commentators in the field expressed concern over whether voters who were new to voting by mail would do so successfully.

Mistakes made by voters and administrative problems in the past had resulted in hundreds of thousands of mail ballots being lost in previous elections. ${ }^{22}$ With the volume of mail ballots possibly doubling or tripling, there was heightened concern not only that voters using the mails for the first time might be disfranchised, but that the controversy over problems with mail balloting would spill over into creating doubts about the legitimacy of the election. Efforts by election officials, civil society actors, and courts addressed these concerns. In the end, voters returned their ballots quickly and they followed directions.

Fears also arose over late-arriving ballots. All states have deadlines for the receipt of mail ballots. Most require ballots to be "in hand" by the close of polls on Election Day. A few allow ballots to arrive after Election Day, so long as there is proof (usually with a postmark) they were mailed by Election Day. In either case, a late-arriving ballot is not counted. Faced with millions of new mail voters and the dysfunction of the postal service, worries arose that

\footnotetext{
20 The rate of mail ballot usage among voters in states that mailed an application to all registered voters was virtually identical (48.8 percent) to voters in states that did not (47.6 percent).

21 The statistical analysis referenced here is available from the authors upon request.

${ }^{22}$ Charles Stewart III, "Reconsidering Lost Votes by Mail," Harvard Data Science Review 2(4), https://doi.org/10.1162/99608f92.6c591bd4.
} 
thousands of voters would be disfranchised because their mail ballots arrived too late to be counted. In 2016, late arrival was the second-most-common reason for the rejection of mail ballots. $^{23}$ Would the same happen in 2020 ?

It appears not. Although comprehensive statistics have yet to be published, examination of absentee ballot files in a few states reveals that a surprisingly small number of mail ballots arrived after Election Day. Georgia, for instance, saw the number of ballots returned after Election Day (and thus rejected) fall from 0.8 percent of ballots returned in 2016 to 0.2 percent in 2020. Consequently, although the number of mail ballots cast grew six-fold, the number of ballots rejected for arriving too late grew only 1,836 to 2,368 . Similarly, the fraction of ballots received after Election Day in Wisconsin fell from 1.4 percent to 0.1 percent, resulting in a small numerical increase in late-arriving ballots $(1,277$ to 1,508$)$, despite the number of ballots cast by mail growing more than ten-fold, from 91,000 to nearly 1.4 million.

In North Carolina, the deadline for the receipt of absentee ballots after Election Day was lengthened from the normal three-day period to nine because of the coronavirus pandemic, as part of a legal settlement with the North Carolina Alliance for Retired Americans. ${ }^{24}$ In the course of the election, the number of mail ballots rose five-fold, from 198,035 in 2016 to 1,026,364. Yet, the number of ballots that arrived after Election Day during the lengthened nine-day period, was barely 5,000 more than $2016(11,489$ vs. 16,313). Indeed, the number of ballots that were rejected for arriving too late actually declined from 1,038 in 2016 ( $0.5 \%$ of all mail ballots) to 797 in $2020(0.08 \%)$.

23 "The Election Administration and Voting Survey: 2016 Comprehensive Report," 11, U.S. Election Assistance Commission, https://www.eac.gov/sites/default/files/eac assets/1/6/2016 EAVS Comprehensive Report.pdf.

24 This settlement was challenged by Republican legislative leaders, but upheld by the U.S. Supreme Court by a 5-3 majority. See Christopher Middleton, "North Carolina: 2020 Election Policies \& Practices," Stanford-MIT Healthy Elections Project, n.d., https://healthyelections.org/sites/default/files/202011/northcarolina-110220.pdf. 
Responses to the SPAE indicate that a greater percentage of mail voters reported returning their ballots more than a week before Election Day $(73 \%)$ than in the past two presidential elections (61\% in each). Detailed examination of absentee ballot administrative files in Oregon, North Carolina, and Wisconsin confirm that voters in these states, which maintain detailed records, conformed to the survey results.

Finally, preliminary evidence suggests that mail ballots were rejected at much lower rates in 2020 than in 2016. Final statistics from the 2020 election will not be available until the EAC releases its Election Administration and Voting Survey (EAVS) in the summer. The website FiveThirtyEight reported that rejection rates were down in 20 of the 23 states (including D.C.) from which it could gather data, compared to $2016 .^{25}$ The website Ballotpedia, relying on different data sources in some cases, reported that rejection rates were down in 14 of 20 states. $^{26}$

Direct analysis of the absentee ballot files from the states that make them readily available tells a similar story. For instance, Wisconsin reported that only $0.2 \%$ of absentee ballots were rejected for any reason, compared to $1.8 \%$ in the April presidential primary and $2.3 \%$ in the 2016 presidential election. ${ }^{27}$ The percent rejected for "certification insufficient," which includes a missing voter or witness signature or a missing witness address, was $0.07 \%$ (1,434 ballots out of nearly two million returned). Georgia saw the number of mail ballots returned for counting grow from 208,617 in 2016 to 1,307,403 in $2020 .{ }^{28}$ The overall number

\footnotetext{
25 Nathaniel Rakich, “Why So Few Absentee Ballots Were Rejected in 2020," FiveThirtyEight, 17 February 2021, https://fivethirtyeight.com/features/why-so-few-absentee-ballots-were-rejected-in-2020/. 26 "Election results, 2020: Analysis of rejected ballots," Ballotpedia, 10 February 2021, https://ballotpedia.org/Election results, 2020: Analysis of rejected ballots.

27 "November 3, 2020 Election Data Report," Wisconsin Elections Commission, 3 February 2021, https://elections.wi.gov/sites/elections.wi.gov/files/202101/D.\%20November\%202020\%20Election\%20Data\%20Report.pdf.

${ }^{28}$ Here we include ballots recorded as arriving after November 3 because the bulk of ballots rejected for signature problems are recorded as arriving after that date. This fact, and other details in the state absentee file, suggest that counties regularly entered the date of rejection, rather than the date of receipt, for these ballots.
} 
rejected in 2020 was 4,003 ( $0.3 \%$ of returned ballots), down from 6,056 (2.9\%) in 2016. Of those rejected in 2020, 1,563 were for either missing or invalid signatures.

In North Carolina, of the 1,011,74 mail ballots returned in time for counting (and not spoiled by the voter), only 10,179 were uncounted (1.0\%), the vast majority of which were for deficiencies with the witness certification. In contrast, in 2016, of the 195,402 returned mail ballots, 3,801 (1.9\%) were uncounted.

\section{The maintenance of in-person voting}

Although the shift to voting by mail was the focus of public attention on the administrative side of conducting the election, election officials were equally attentive to the challenges of maintaining polling places for Election Day and early voting. Even with the shift of so many voters to mail balloting, maintaining polling places remained critical to the safe and effective conduct of the election, because some voters needed services that could only be provided inperson, others distrusted the postal service, and still others heeded President's Trump's calls to vote in person, and many voters would either need or strongly desire to vote in person. ${ }^{29}$

With respect to retaining polling places, one report indicated that 21,000 polling places had been eliminated in 2020 compared to 2016, out of approximately 100,000 that had been used that year. ${ }^{30}$ Half of the eliminated polling places were in California alone, which mailed ballots

\footnotetext{
${ }^{29}$ In an August poll by the Pew Research Center, before any states had begun the distribution of mail ballots, $60 \%$ of Trump supporters, compared to $23 \%$ of Biden supporters, stated an intention to vote on Election Day. African Americans were the demographic group most likely to express a preference to vote early and in person. See "Views of the 2020 campaign and voting in November," Pew Research Center, 13 August 2020, https://www.pewresearch.org/politics/2020/08/13/views-of-the-2020-campaign-andvoting-in-novemberl.

${ }^{30}$ Cameron Joseph and Robert Arthur, "The U.S. Eliminated Nearly 21,000 Election Day Polling Locations for 2020," VICE News, 22 October 2020, https://www.vice.com/en/article/pkdenn/the-useliminated-nearly-21000-election-day-polling-locations-for-2020. We thank Cameron Joseph for sharing the data that were the basis of that report.
} 
to all registered voters. Most of the other states with the biggest percentage drops in the number of polling places either mailed ballots to all registered voters (Nevada, New Jersey, and Vermont) or worked hard to divert voters to early voting and voting centers (Maryland and Kentucky).

Respondents to the SPAE indicated that the type of facility they voted in was different in 2020 than in recent elections. Between 2008 and 2016, the three most-common polling places were schools (25 percent of in-person voters), churches (17 percent), and community centers (16 percent). In 2020, the top three were "other" government buildings (i.e., court house, municipal building, or city hall, but not schools, community centers, firehouses, or police stations) at 23 percent, 21 percent in community centers, and 18 percent in schools. In other words, in-person voting shifted to larger facilities that local governments had greater control over.

Although we cannot yet document precisely how well local officials maintained access to in-person voting, we can assess the experience of voters who cast ballots in person and judge indirectly how well the system performed. Here, as with mail voting, the conclusions are mostly positive, although there are signs they were far from perfect.

First, despite the net reduction of 21,000 polling places and the relocation of thousands more, in-person voters did not report greater difficulty finding their polling place in 2020. Second, among the other measures that the SPAE has followed over the year to assess the experience of in-person voters, 2020 was no different from past years. Third, in-person voters largely encountered polling places where they felt that safety measures were appropriately in place. $^{31}$

31 Charles Stewart III, "How We Voted in 2020: A First Look at the Survey of the Performance of American Elections," MIT Election Data and Science Lab, December 15, 2020, at http://electionlab.mit.edu/sites/default/files/2020-12/How-we-voted-in-2020-v01.pdf. 
On the other hand, other public health measures were less often in presence. Barely half of in-person respondents ( 56 percent) reported that voting booths were spaced out to respect social distancing, 47 percent reported barriers between them and the poll workers, 42 percent reported that they saw voting booths cleaned between uses.

The one measure on which voters reported having a worse experience than in 2016 was the time spent waiting to vote in person. The benchmark we use is the percentage of in-person voters who waited more than 30 minutes to vote, either on Election Day or during early voting. The 30-minute mark is chosen because that was the standard suggested by the Presidential Commission on Election Administration in its 2014 report. ${ }^{32}$ Given the demands of social distancing and the assumed reduction in flow of voters into closed polling places, we might expect longer lines for voting in 2020.

In fact, wait times were up in 2020, and up to levels seen in 2008, the election year with the longest wait times on record. Roughly one-in-five early voters waited more than half an hour to vote, as did one-in-seven Election Day voters. The racial gap in wait times had closed for Election Day voting in 2016, but remained open for early voting. The same remained true in 2020, just at longer wait times. In 2016, $8.5 \%$ of both whites and blacks waited more than 30 minutes on Election Day. In 2020, $14.3 \%$ of whites and $15.6 \%$ of blacks waited more than 30 minutes on Election Day, a small and statistically insignificant difference. On the other hand, 26.6 percent of black early voters, compared to 20.5 percent of white early voters, waited more than 30 minutes to vote. This six-point gap was similar to the nine-point gap (18.0 percent vs. 9.2 percent) in 2016 .

32 "The American Voting Experience: Report and Recommendations of the Presidential Commission on Election Administration," U.S. Presidential Commission on Election Administration, January 2014, http://web.mit.edu/supportthevoter/www/files/2014/01/Amer-Voting-Exper-final-draft-01-09-14-508.pdf. 


\section{The Gap Between Perception and Reality}

The story told here of a historic and heroic administration of the 2020 election is one based on the observed facts and data. A competing narrative of dysfunction and a "stolen election" emerged in the election's aftermath, of course, as propagated by President Trump and his supporters. Seeds of that narrative actually preceded the election, as President Trump and his surrogates had primed the American public, and more particularly, his supporters, to expect fraud of historic proportions, and for his loss, were it to come, to be caused by that fraud. That lie then became weaponized on January 6, as the "Stop the Steal" movement descended on the Capitol for a deadly attempt at insurrection.

Partisan polarization concerning the fairness of a presidential election is not new, and to a large degree the basic patterns in 2020 mimicked what political scientists have found over the past two decades. In the case of 2020, roughly half of respondents to the Economist/YouGov series of polls between August and Election Day reported they had "a great deal" or "quite a bit" of confidence that their own votes would be counted accurately in the upcoming election (socalled "egotropic confidence"); between thirty and forty percent answered they had a great deal or quite a bit of confidence the election would be "held fairly" ("sociotropic confidence"). Democrats were slightly more confident by both measures and Republicans were slightly less confident.

[Figure 5 about here]

After Election Day the overall measure stayed roughly unchanged, but the degree of partisan polarization exploded. Before the election, Democrats were 10.9 points more confident their votes would be counted accurately than Republicans; after Election Day, this gap was 51.7 
points. The increased gap in trust that the election would be fair was even greater, from 15.0 points pre-election to 72.6 points post-election.

In some ways, the separation of the parties on their assessment of the election's fairness can be attributed to the "winners and losers effect" that has been documented in studies of voter confidence. ${ }^{33}$ However, in comparison to recent elections, the gap is extreme. Sances and Stewart examined the pre-to-post-election change in voter confidence across the presidential elections from 2004 to 2012, for instance, using a "differences in differences" method. ${ }^{34}$ They found that on average the gap between the parties increased 22 points on the question about confidence in one's own vote and 32 points in confidence about the election as a whole. Using the same method, we find that the net change in 2016 was similar -17 points and 18 points, respectively. In contrast, the net gaps in confidence and trust opened up 41 points in 2020 on the issue of one's own vote and 58 points on the issue of the election's fairness overall.

Although the yawning gap between the two parties in how they view the accuracy and fairness of the 2020 election is perhaps historic, the degree of partisan mistrust that has opened up at the state and local levels is also new and will likely have more important near-term consequences, because of the preeminent role states play in determining election policy. In the past, even when the two parties disagreed about the fairness of the national result, they were

\footnotetext{
${ }^{33}$ Michael W. Sances and Charles Stewart III, "Partisanship and confidence in the vote count: Evidence from U.S. national elections since 2000," Electoral Studies 40 (2015): 176 - 188; Betsy Sinclair, Stephen S. Smith, and Patrick D. Tucker, "It's largely a rigged system: Voter confidence and the winner effect in 2016," Political Research Quarterly 71 (2018): 854 - 868.

34 The method is this: First, calculate the gap in confidence between supporters of the winning candidate before the election and pre-election confidence of supporters of the losing candidate. This is the preelection difference. Second, calculate the same gap after the election. This is the post-election difference. Third, calculate the difference-in-differences, which is simply the post-election difference minus the pre-election difference. In 2020, for instance, the average pre-election gap on the question about one's own vote was 11 points (Democrats more confident), the average post-election gap was 52 points, and the difference between the two was 41 points, which is the estimate reported in this paragraph.
} 
willing to acknowledge that local elections were conducted well, with only a small dose of loser's effect thrown in. And, as recently as 2016, the two parties were virtually identical in how they judged state and local election administration.

Not so in 2020. Survey research data about attitudes toward the accuracy of state election results reveals that the most dissatisfied Republicans live in states that Trump barely lost, and that the chasm in trust among Republicans where he barely lost and where he barely won is also vast.

Data from the Survey of the Performance of American Elections, which is designed to probe attitudes about election administration at the state level, helps to illustrate the point. Figure 6 plots the percentage of respondents from the two parties who were either very or somewhat confident that votes in their state were counted as intended against the percentage of the twoparty vote received by Trump. The discontinuity right at the $50 \%$ mark in the Republican graph is quite stark. Simply living in a state Trump barely won is worth approximately 40 points in confidence in whether state votes were counted properly among Republicans, compared to living in a state Trump barely lost.

[Figure 6 about here]

A closer examination of the Republican graph also reveals two other important points. Republicans report being especially discontent with the state vote count where Trump lost by less than three points - with the exception of Arizona, all are significant negative outliers from the least-squares line drawn in the figure. Second, Republicans were even more dissatisfied in states where the use of mail ballots was especially high — note the significant negative outliers among Maryland, California, Washington, Oregon, and New Jersey — and much less dissatisfied 
in states where mail ballot usage was low - note the significant positive outliers among

Connecticut, Delaware, New Hampshire, and Maine. ${ }^{35}$

Democrats show a much smaller state confidence discontinuity at the point that defines a Trump victory, only 4.6 points. The two negative outliers close to the $50 \%$ discontinuity are Florida and Texas. Unlike the Republican graph, the usage of mail ballots had no influence on the attitudes of Democrats toward state vote counting, either in states Trump won or lost.

Exploring other years, but not displayed here, the Democratic graph for 2020 is more typical of the relationship between the state vote margin of the candidates and the confidence of state partisans. There is slightly more dissatisfaction among partisans in the battleground states depending on which side of 50 percent one's candidate landed on, but the gap is in the 5-point range, not the 40 points we see in 2020 .

In almost every state, Democrats are more confident in the 2020 vote count than Republicans, and by a lot. It is unsurprising, therefore, that immediately after the election news reports of efforts by Republican legislators in these states to rein-in forms of voting that seemed to be favored by Democrats began to be surfaced. Scores of bills to restrict mail balloting have been filed by Republican legislators throughout the country, but the states with the most legislative activity are Arizona, Pennsylvania, Georgia, and New Hampshire. ${ }^{36}$

\footnotetext{
35 This point is confirmed by a simple multiple regression in which we add the percentage of ballots cast by mail to the lines fit in the two figures. Among Republicans in states that Trump lost, each percentage point increase in the use of mail ballots decreased state-level confidence by 0.239 points; in states that Trump won, the corresponding coefficient is 0.002 points. The former effect is significant at $p<.026$; the latter as a $p$-value of .967.

36 "Voting Laws Roundup: February 2021," Brennan Center, 8 February 2021, https://www.brennancenter.org/our-work/research-reports/voting-laws-roundup-february-2021.
} 


\section{Conclusion}

How the country interprets the 2020 election will, in many respects, shape the future of American democracy. The electoral system confronted and passed its most severe test in recent memory. Any fair appraisal would focus on the heroism of election officials, civil society actors, and voters, who turned out in record numbers despite the threat of a pandemic. It would lead to renewed attention to the needs of election officials and the changing expectations of voters who increasingly seek flexibility in how they vote.

That legacy is far from guaranteed, however. The doubt cast on all aspects of the electoral process, from voting machines to ballot drop boxes to mail balloting, threatens Americans' faith in the machinery of democracy and in those who dedicate their lives to administer it. On the receiving end of death threats and hate mail, a large number of those officials who administered the 2020 election are anticipating retirement, citing the political pressures of the job as a primary reason. ${ }^{37}$ It remains to be seen who will volunteer to step into these positions, given the pressure, low pay, threats, and lack of support from political leaders.

One consequence of the election may be a leadership crisis in election administration, as exhausted and frustrated incumbents step down and state and local governments struggle to find replacements who are equally dedicated to tireless and fair implementation of election laws. An even worse future will be in store if the next generation of election officials who step forward do so out of a conviction that the 2020 election was fundamentally flawed.

${ }^{37}$ Fredreka Schouten and Kelly Mena, "High-profile election officials leave posts after a tumultuous 2020," CNN, 19 February 2021, at https://www.cnn.com/2021/02/19/politics/election-officials-lose-andleave-jobs/index.html. Also see Marie Albiges and Tom Lisi, "Pa. election officials are burnt out and leaving their jobs after 2020 'nightmare,"' Philadelphia Inquirer, Spotlight PA, 21 December 2020, https://www.inquirer.com/politics/election/spl/pennsylvania-election-2020-officials-retiring-nightmare20201221.html. 
For long-time observers of election administration and law, the 2020 election offers a number of obvious lessons learned that should demand immediate attention in state capitals and Washington, while the memory of the election is fresh. Among these are sufficiently funding election administration, clarifying emergency legislation relating to elections, cementing ties between election officials and social media outlets for communicating with voters, enacting comprehensive post-election auditing programs, developing workable observation procedures, and fully acknowledging the critical role of the U.S. Postal Service in conducting elections. Other obvious issues are regularizing the use of drop-off locations for mail ballots, requiring greater use of the internet to track absentee ballots and manage mail-ballot transactions, establishing uniform standards for curing deficiencies of absentee ballots, reforming the Electoral Count Act of 1887, and declaring Election Day a school holiday. ${ }^{38}$

Instead, the motivating memory driving much election administration lawmaking are amplified through a continued barrage of false claims about the election. As state legislatures convene and begin their work, efforts to restrict absentee voting — by instituting heightened ID requirements, shortening the period when they can be requested, or to eliminate no-excuse absentee voting — are garnering the most attention. By the end of February, the database maintained by the NCSL tracking all proposed election legislation in the states had identified 3,275 bills that had been filed, over half of which addressed absentee or mail voting. ${ }^{39}$ While some of these bills are earnest attempts to adapt what was learned from the 2020 election to future mail-ballot policy, in most states these bills will likely provoke heated partisan debates

\footnotetext{
38 Nathaniel Persily and Charles Stewart III, A 12-Step Rehabilitation Program for American Election Administration, Lawfare, January 27, 2021, at https://www.lawfareblog.com/12-step-rehabilitationprogram-american-election-administration.

${ }^{39}$ National Conference of State Legislatures, State Elections Legislation Database, at https://www.ncsl.org/research/elections-and-campaigns/elections-legislation-database.aspx.
} 
aimed at re-litigating grievances from the election. The over-attention to mail voting to the neglect of the other pressing issues that arose during the election will result in a lost opportunity to improve the functioning of the election administration system.

The stakes could not be higher as American navigates its way forward. The 2020 election demonstrated how false claims about election fraud can turn deadly. At the same time, the election also demonstrated the resilience of American voters and election administrators. The open question at this point is whether, when we look back on 2020, it will be regarded as the turning point for further strengthening the mechanics of voting, or the moment when a new generation of violent voter suppression began. 
Figure 1. Percent of Ballots Cast by Mail in Presidential Primaries, 2016 and 2020.

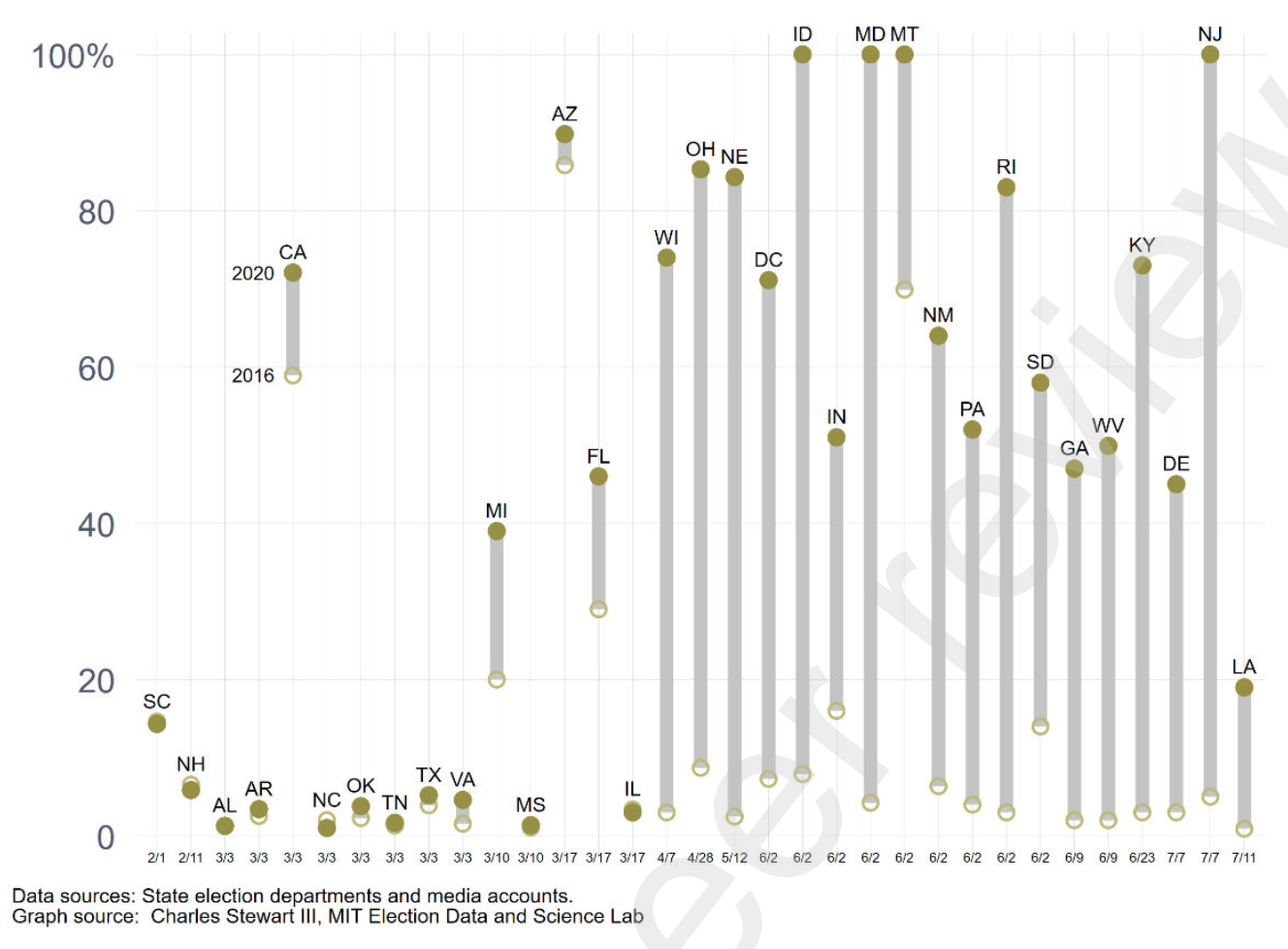

Data sources: Gathered by the Stanford/MIT Healthy Elections Project using state election department reports and media accounts; however, not all states provide data. Only states that held primaries in both 2016 and 2020 are displayed. 
Figure 2. Change in turnout by state, from 2016 to 2020.

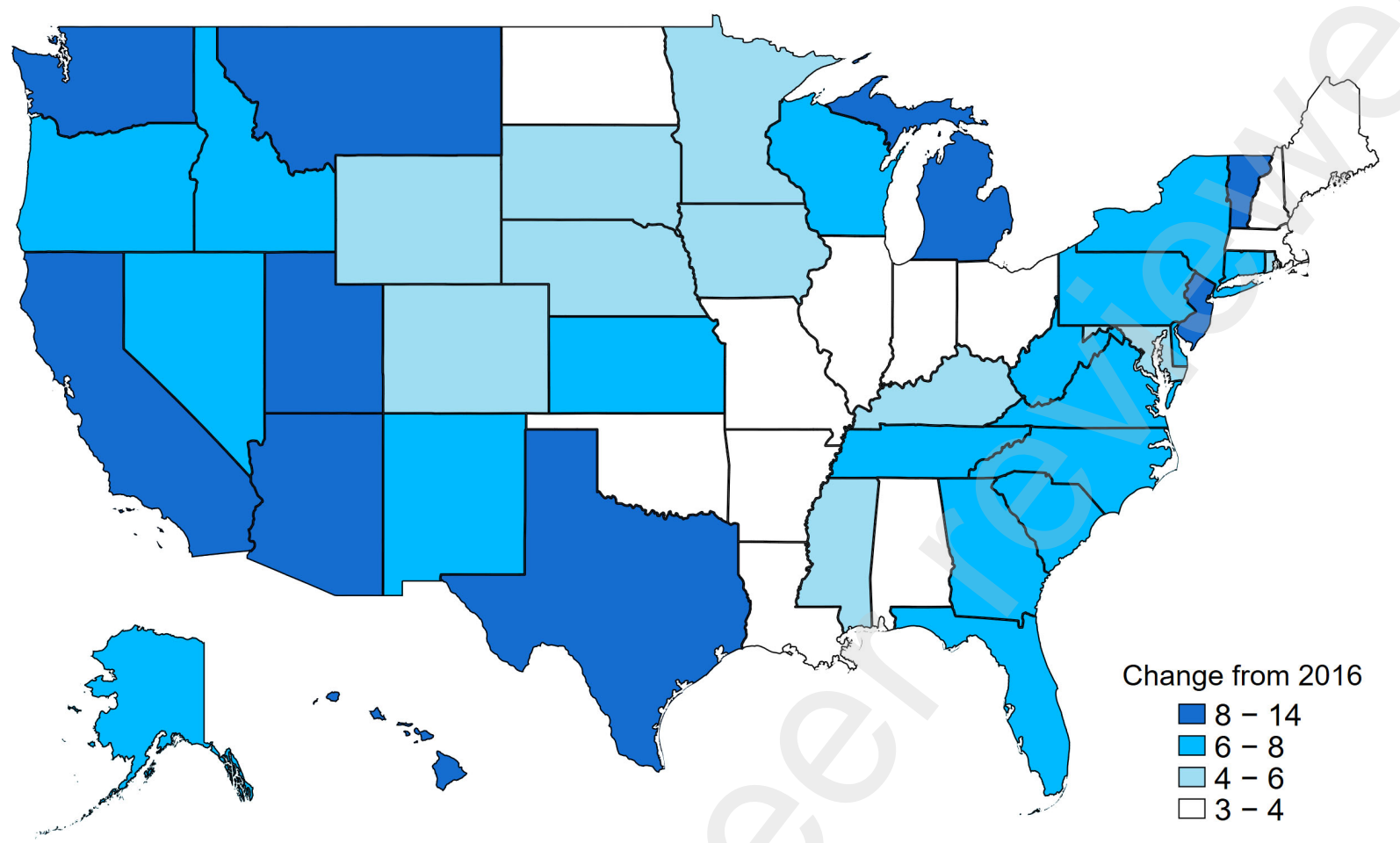

Data source: United States Elections Project. 
Figure 3. Voting on Election Day, early in-person, and by mail, 1996 - 2020.

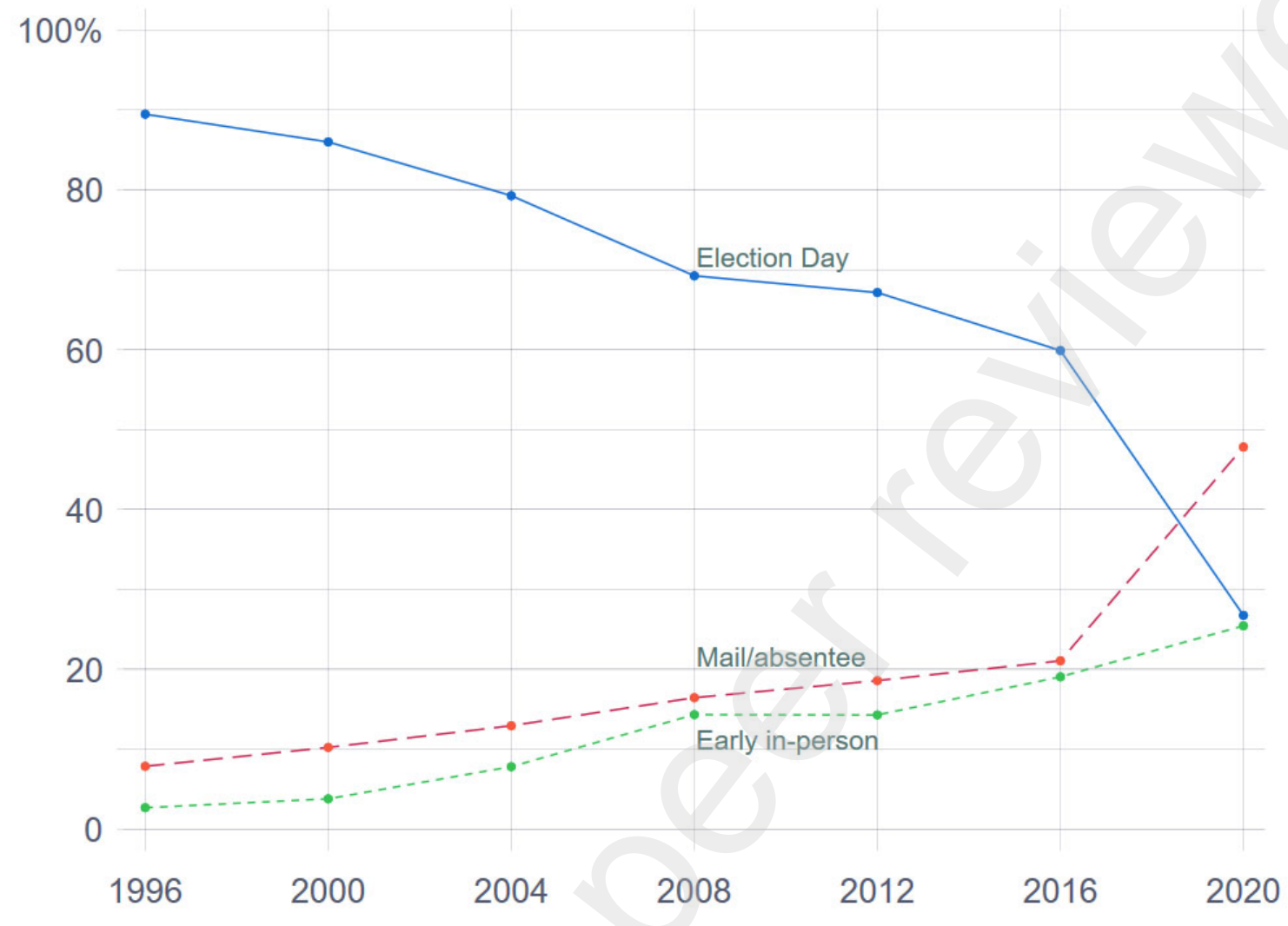

Data sources: U.S. Census Bureau, Voting and Registration Supplement, 1996 - 2016; Survey of the Performance of American Elections, 2020 
Figure 4. Change in distribution of Election Day, early in-person, and mail ballots from 2016 to 2020.

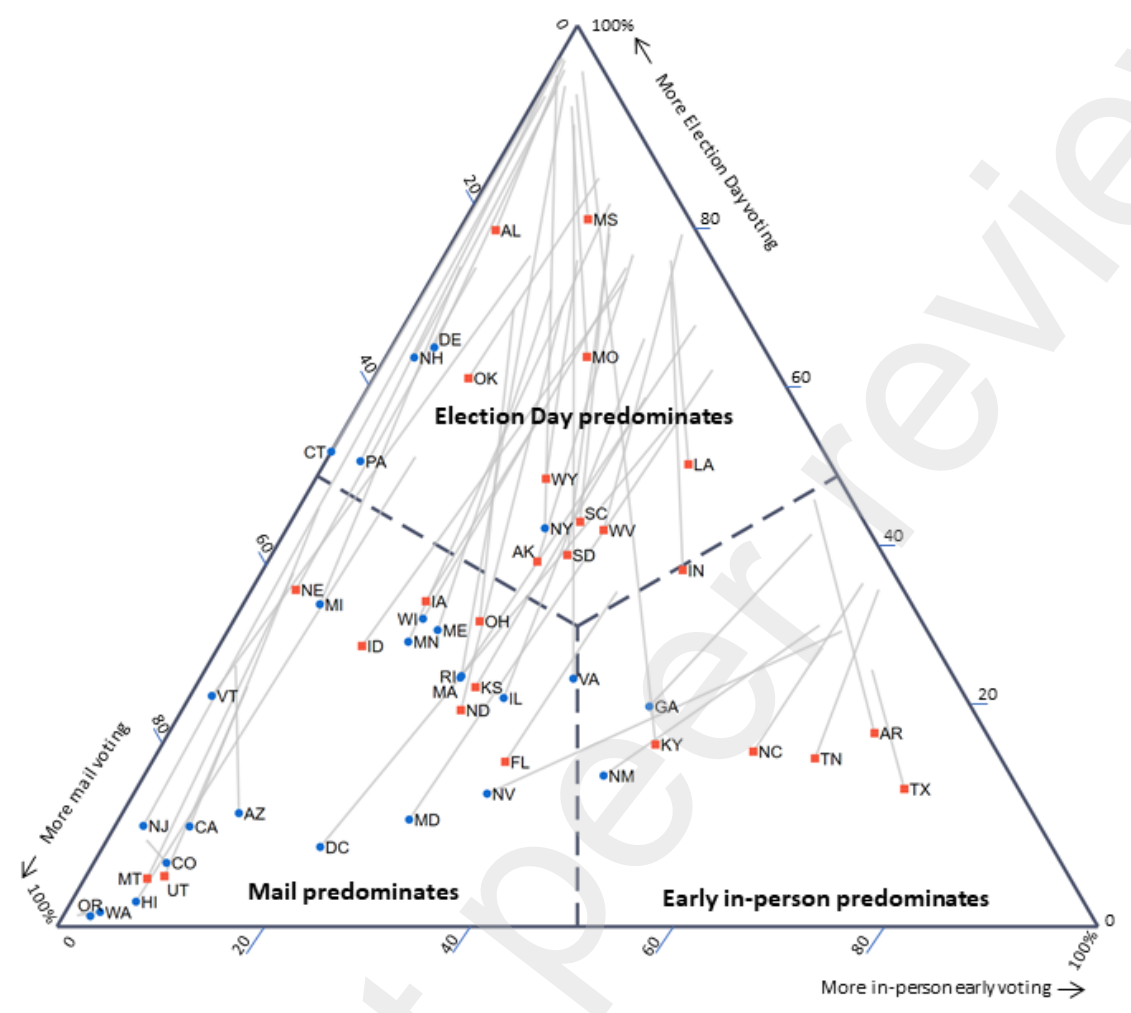

Data sources: U.S. Census Bureau, Voting and Registration Supplement, 1996 - 2016; Survey of the Performance of American Elections, 2020.

Note: Blue circles represent states won by Joe Biden. Red squares represent states won by Donald Trump. 
Figure 5. Degree of trust that one's vote will be counted accurately and that the election will be held fairly.

a. How much confidence do you have that your vote in the 2020 presidential election [will be/was] counted accurately? (Percent answering "a great deal" or "quite a bit.")

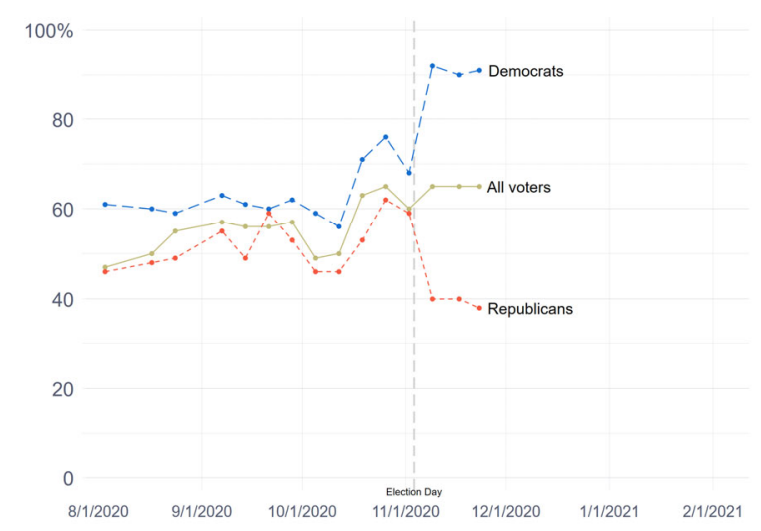

b. How much confidence do you have that the 2020 presidential election [will be held/was held] fairly? (Percent answering "a great deal" or "quite a bit.")

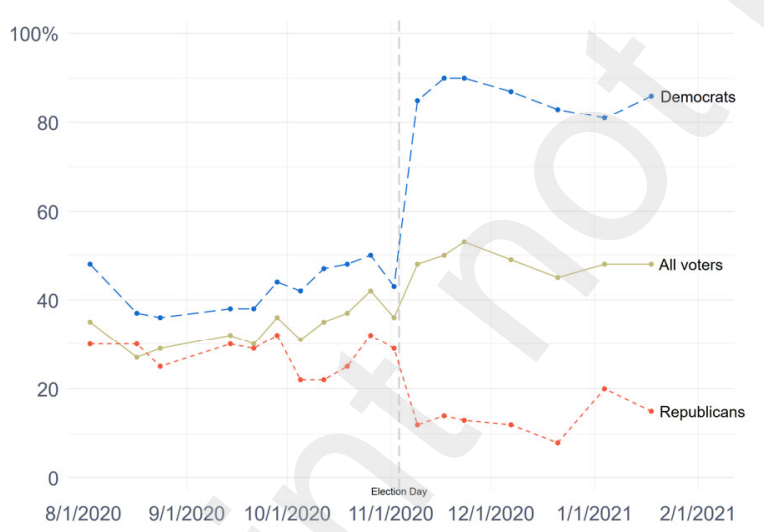

Data source: Economist/YouGov poll. 
Figure 6. Confidence that state votes were counted as intended in 2020, by party.

a. Republican respondents

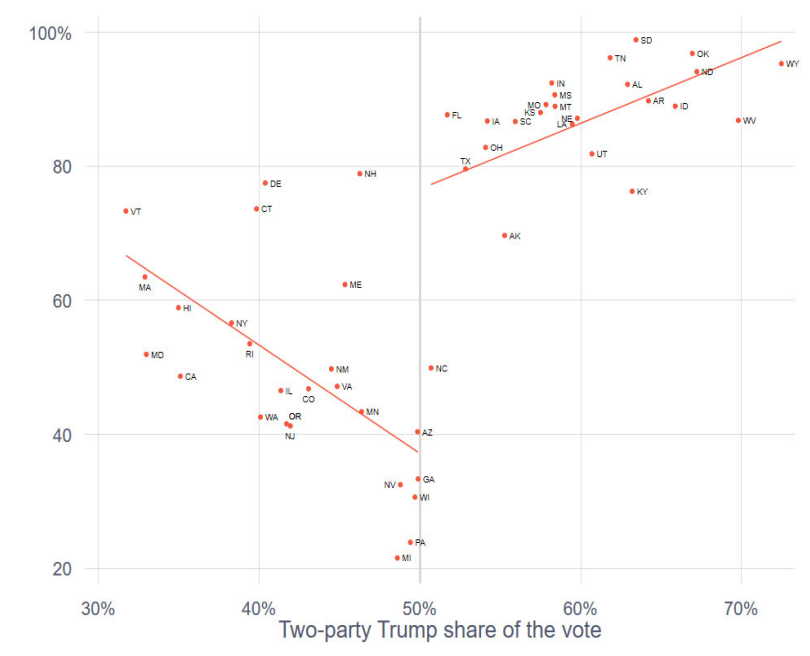

b. Democratic respondents

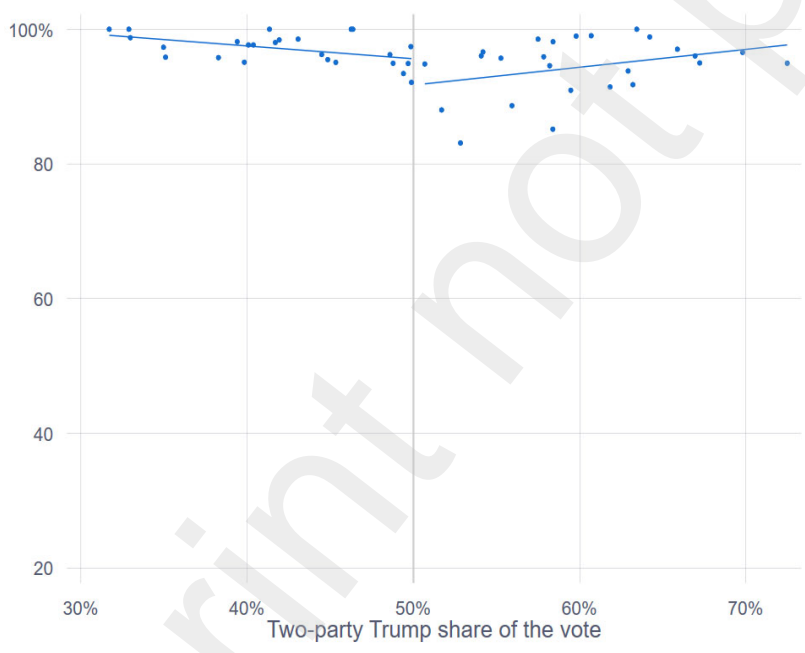

